\title{
Redeploying Bayh-Dole: beyond Merely doing good to optimizing the potential in results of taxpayer-funded research
}

\author{
John E. Tyler III
}

Published online: 10 September 2011

(C) The Author(s) 2011. This article is published with open access at Springerlink.com

\begin{abstract}
Opinions about the Bayh-Dole Act of 1980 and its implementation by US universities can depend on whether one views the Act as a series of tactics that are ends in themselves or as a policy declaration designed to protect the public against nonuse of taxpayer-funded discoveries and encourage their commercialization, utilization, and public availability. Those views appear to influence how universities and their leaders measure performance and define success, identify and allocate resources, approach transfer strategies, and negotiate terms and apportion risks relative to those terms. Those who view the Act as tactical tend to obscure the broader policy objectives which can result in substantial amounts of university research that is "never commercialized" (President's Council of Advisors 2003), "restrained" (Schacht 2010b), and "left unused and unapplied" (Seipman in Univ Dayt Law Rev 30:209-243, 2004). Society then is deprived of the new products, services, approaches and experiences that can stimulate economic growth and advance human welfare. These and other consequences demand evaluations and assessments of university practices and behaviors and the extent to which they narrowly serve the Act's tactics or more broadly serve its purposes of pursuing and maximizing the potential usefulness of the results of taxpayer-funded research. Too frequently, there seems to be a disconnect between federal policy and practices adopted or tolerated by universities and their leaders to implement that policy.
\end{abstract}

Keywords Bayh-Dole - University technology transfer · Advancing university innovation · Autm

JEL Classification 20: Innovation Policy $\cdot 40.015$ : Theory ·

45: University Technology Initiatives $\cdot \mathrm{I} 23 \cdot \mathrm{I} 28 \cdot \mathrm{O} 31 \cdot \mathrm{O} 38$

J. E. Tyler III (ه)

Ewing Marion Kauffman Foundation, 4801 Rockhill Road, Kansas City, MO 64110, USA

e-mail: jtyler@kauffman.org 


\section{Introduction}

Since the Bayh-Dole Act (35 USC § 200, et seq.) became law in the United States in 1980, the number of US universities that have established technology transfer offices has increased significantly. The number of patents issued to US universities has grown similarly, as have the numbers of disclosures by researchers, of patent applications, of spin out companies, and the amount of money generated for US universities from their exploitation of the results of taxpayer-funded research (Pulsinelli 2006). Some have claimed that these outcomes evidence Bayh-Dole's unbridled success (Pulsinelli 2006; Moore 2006), but these measures are not necessarily indicators of the Act's expressly stated purposes of commercialization or utilization (Mowery 2005). In some ways, how one views the Act's achievements depends on whether the Act is interpreted as a series of tactics that are ends in themselves or as a declaration of policy that seeks to maximize the usefulness of the results of taxpayer-funded research through commercialization, utilization, and public availability.

Comparing the above standards of measure against pre-1980 performance, the Act certainly appears to have succeeded, and there was a time when it was appropriate to celebrate these outcomes as important milestones in the effort to maximize the usefulness of university discoveries. However, instead of being viewed as markers that evidence achievement of certain objectives along a pathway, they too often seem to be considered victories in themselves. Such limited perspective, where it exists, promotes complacency and threatens to obscure the broader, more important policy objectives for taxpayer-funded research as stated in federal law, including Bayh-Dole. It also neglects the substantial amount of otherwise usable university research that is "never commercialized" (President's Council of Advisors 2003), "restrained" (Schacht 2010b), and "left unused and unapplied" (Seipman 2004).

Better than it was should never be confused with as good as it could be.

Many universities are centers of research excellence and innovative thinking. They enhance knowledge, understanding, and basic conceptions that can advance economic growth and human welfare. For instance, university innovations have been and can continue to lead to new products, services, approaches and experiences that can help stimulate economic growth and corresponding potential for jobs, taxes, wealth, and other community benefits (Litan and Cook-Deegan 2011; Tyler 2009; Schramm 2006; Tornatzky 2002; Good 2004; Thursby and Thursby 2004). The United States government clearly values that role. It annually directs tens of billions of dollars to such universities for their research efforts. These funds and the research that they support serve a "critical national need" that is "vital to the nation's welfare and security" because of the potential contributions to our nation's economic growth and well-being, which is increasingly being viewed as a composite of national security (Schacht 2010b; President's Council of Advisors 2008; Crow 2008).

University innovations also can advance human welfare by alleviating hunger and other suffering, creating efficiency, enhancing communications, facilitating safety, and treating, curing, and/or preventing illness (Litan and Cook-Deegan 2011; Tyler 2009). These possibilities are too important to risk being "left unused and unapplied."

As summarized below, US policy embraces pursuing both the commercial and usefulness potential of research results. Although the purposes of Bayh-Dole are presented in a context of encouraging use of the patent system to further those goals, the overall policy pronouncements should not thereby be limited to patenting activity. Other federal policy declarations support the character of the Act as transcending patent strategies. By overly 
focusing on patenting, US universities and adaptations by other nations are not fully adopting Bayh-Dole's broader purposes and are under-realizing its potential.

Among the Act's essential purposes are promoting and encouraging the following:

- Use of inventions arising from federally supported research or development;

- Collaboration between commercial concerns and nonprofit organizations, including universities;

- Free competition and enterprise without unduly encumbering future research and discovery; and

- Commercialization and public availability of inventions made by United States industry and labor.

(35 USC § 200). Legislative history further identifies motives for the Act as including the following belief:

[The Act] will lead to greater productivity in the United States, provide new jobs for our citizens, create economic growth, foster increased competition, make Government research and development contracting more competitive, and stimulate a greater return on the billions of dollars spent each year by the Government on its research and development programs

(Clements 2009; S. Rep. No. 96-480, at 1, 3 (1979)). The Act, therefore, emphasizes commercialization and utilization or public availability along with collaboration, free competition, and enterprise.

Congress also chose the Act as a vehicle to communicate an over-arching concern about the need to "protect the public against nonuse or unreasonable use of inventions" (35 U.S.C. § 200). In other words, ensure that the results of taxpayer-funded research are deployed and that nonuse does not deny the potential economic growth opportunities and advances in human welfare that might flow from such research (NRC 2011).

These purposes are consistent with other Congressional expressions of federal policy that emphasize its intent to maximize the usefulness of the results of federally funded research. For instance, in the Stevenson-Wydler Technology Innovation Act of 1980, Congress explicitly declared "a strong national policy supporting domestic technology transfer and utilization of the science and technology resources of the Federal Government" in furtherance of a comprehensive national policy to enhance technology transfer for both commercialization and public purposes (15 U.S.C. § 3701(8)). Congress envisioned renewed, expanded, and stronger cross-sector cooperation among government, academia, and industry through "technology transfer, personnel exchange, joint research projects, and others" (15 U.S.C. § 3701(3)). Congress expressly tied these declarations to the "continuing responsibility of the Federal Government to ensure the full use of the results of the Nation's Federal investment in research and development" (15 U.S.C. § 3710(a) (1)).

The National Institutes of Health and the National Research Council of the National Academies have also stressed the importance of maximizing public and social benefits of results of taxpayer funded research, including commercialization, dissemination, and utilization (NIH 1999, 2005; NRC 2011).

Additional purposes for university innovation include furthering state and community economic development efforts (15 U.S.C. \$§ 3701(9) and 3702(3); Schacht, 2010a; Paytas, 2004; Tornatzky, 2002; Palmintera 2005; Coffman et al. 2003; Good 2004).

Some argue that industry and government bear responsibility for failures in fulfilling the Act's purposes. Others contend that US universities in fact are fulfilling these purposes and that there is no data to support conclusions to the contrary. Part two of this article addresses 
these other aspects of the advancing innovation ecosystem, in part, by distinguishing between progress toward fulfilling these purposes and actually fulfilling them.

Part three of this article explores how university practices and behaviors can reflect how university leaders perceive and prioritize approaches to implementing applicable federal policy. Part three also considers how practices and behaviors can interfere with or facilitate the Act's policy objectives of maximizing the potential of the results of taxpayer-funded research. Among these relevant practices and behaviors are (1) the outcomes that university leaders use to measure and evaluate performance, (2) the nature of resources they dedicate to advancing innovation efforts, and (3) the philosophical and practical approaches they support for technology transfer, including general theories of negotiation, approaches to intellectual property, and strategies for allocating risk.

This article is not an attack on Bayh-Dole but is a critique of how many university leaders have implemented it. There are opportunities to achieve even better results that could leave fewer university discoveries orphaned and in the process enhance opportunities for economic growth and advances to human welfare. Among these opportunities are better emphasizing the purposes and broad objectives for Bayh-Dole and more clearly communicating that the tactics are intended as means to desirable ends rather than ends themselves, including that the tactics are not exclusive and may not even be preferred in many circumstances. Finally, there are opportunities to more expressly connect university practices and behaviors in service to the purposes and ultimate policy objectives rather than to tactics.

\section{Non-university factors in the advancing innovation ecosystem}

The purpose of this article is not to suggest that any and all problems with or impediments to advancing university innovations originate with universities or with their technology transfer offices. To the contrary, industry and government also contribute to the problems.

For instance, industry often fails to appreciate that US universities must comply with a regimen of laws and regulations relating to their status as either governmental bodies or public charities under $\S 501$ (c)(3) of the Internal Revenue Code. Among these are mandates to operate in furtherance of exempt, charitable, and educational purposes and not to permit private benefit (President's Council of Advisors 2008; Clements 2009; Bohlander 2004). Consequently, universities have a legal mandate to ensure prompt dissemination of research results as a condition of retaining exempt status (Schacht 2010a). In addition, universities must ensure that technology transfer arrangements do not jeopardize their tax exempt status and that terms and provisions reflect reasonable, fair value, market conditions. Universities also can be as concerned about having been taken advantage of and missing out on a financially lucrative opportunity as they have been criticized for overvaluing intellectual property and under-appreciating that most university innovations are early stage, of generally unknown usefulness, high risk, and very expensive to take to market (Nilsson 2006; Mowery et al. 2004; Schacht 2010a, b).

Overly aggressive industry demands regarding access to research results, failure to properly address conflicts of interest, and unnecessarily strict prohibitions on timeliness of publication or sharing of information can all interfere with proper academic priorities.

It should not need to be stated how wrong it is for industry to impose pressures on university researchers to falsify or suppress data, to neglect legitimate methodologies and/ or pursue those that are less legitimate, to obfuscate or vary results, or in any other way to mischaracterize the search for knowledge that should still be at the core of university 
research activities; unfortunately, such industry practices and even university complicity are not beyond imagining (Washburn 2005). Of course, the academy's experiences with similar pressures or activities pre-date Bayh-Dole and occur without regard to industry engagement as the desire for recognition, priority, and rewards compete with dissemination and advancement (NRC 2011). But even perceptions of industry influence over the university or its researchers can create a different set of problems that might lead to unduly restrictive overreactions in the name of protecting and appearing to protect academic integrity and freedom.

In some ways, the US government also complicates these efforts. For instance, Congress has unequivocally declared in Bayh-Dole and elsewhere the importance of university efforts to commercialize and use research results, collaborate with industry, and pursue local and regional economic development opportunities. Legislative and Internal Revenue Service inquiries into and expressions of skepticism about university efforts along these very lines convey a contradictory message that can leave university leaders understandably perplexed and victims of an avoidable (and undesirable) catch-22.

However, the fact that industry and government can interfere with and impede efforts to advance university innovations does not justify advocating for the status quo or actually maintaining it.

It is also not the purpose of this article to suggest-nor should it be inferred-that there are no US universities that are good at advancing their innovations or even that maximize the potential of the results of their taxpayer-funded research. To the contrary, several institutions have remarkable, long, and admirable records of success. There is a great deal to be learned from these institutions (Markman et al. 2005), and this article draws from those lessons and experiences. However, the available data suggests that very few US universities generate substantial revenue and even within those universities a small number of innovations typically account for most of the revenue (Litan and Cook-Deegan 2011; NRC 2011; Pizzo 2007; de Larena 2007; Lambert and Butler 2006; Nilsson 2006; Bok 2004b; Good 2004; Mowery et al. 2004; Seipman 2004; Stein 2004). In addition, the low number of strong programs when compared against the several hundred programs that exist suggests that there is room for improvement.

It is not appropriate to tolerate mediocrity or worse because a few programs shine brightly. To use an analogy that deliberately overstates the case, the fact that an automobile's body is un-dented, sharp, clean and shiny does not mean that the engine and transmission are functioning optimally. Problems with the engine, transmission, and electrical systems need to be independently assessed and fixed in order for the vehicle to be safe, sound, and operational. Using a different analogy, a health care professional would be committing malpractice by declaring a patient fit and well by focusing only on healthy organs and tissues and otherwise neglecting symptoms and evidence of ill-health.

Conclusions that university technology transfer efforts are not optimizing potential have been attacked as flawed and misguided because there is no supporting data. In other words, because there are no definitive statements of potential, there can be no way to determine whether that potential is being achieved or not. It therefore follows, the argument continues, that criticisms grounded in pursuing potential lack merit and the status quo should be complacently maintained. Stated differently, the attack argues that barriers to doing better and impediments to advancing economic growth and human welfare should be sustained because an ideal or even improved state cannot be objectively declared or realized with certainty.

Admittedly, there is no unequivocal, absolute data such as that which such critics seek, but there are analyses that can be done of the financial returns on funds invested in research that would show such returns as deficient (Litan and Cook-Deegan 2011; Tyler 2009). For 
instance, Litan and Cook-Deegan found a range of $0.3-4.3 \%$ as the average annual percentage return on expenditures for the top ten recipients of cumulative licensing income between 1996 and 2008. Four of those ten had an average annual return of $0.5 \%$ or less; five had returns greater than 1\%; and only two had returns higher than $2 \%$ (2011).

Such an analysis, however, over-emphasizes monetary returns and neglects other important contributions (Litan and Cook-Deegan 2011; Tyler 2009). But it seems ironic and paradoxical that one of the standards of measure most emphasized by university leaders - revenue - is argued as inadequate or irrelevant when presented as a counter point to encourage the need for improvement.

The absence of an ideal or perfect foil against which to measure performance, however, is not a prerequisite for evaluating performance and making suggestions for improvement. For instance, there are other indicators of suboptimal performance, including the extent to which researchers use "backdoor" approaches to avoid technology transfer offices (Litan and Cook-Deegan 2011; Audretsch and Aldridge 2010; Thursby et al. 2009) and research productivity (Litan and Cook-Deegan 2011). Moreover, it is possible to analyze systems, processes, and practices and identify obvious barriers to the ultimate goals that if removed are likely to enable progress toward those goals (Tyler 2009; see Litan and Cook-Deegan 2011). It also may be inferred from continued tolerance of those barriers, when assessed in a broader context, whether university leaders focus on Bayh-Dole's tactics or its more important policy purposes with the attendant consequences.

Although there is context to be gained from appreciating that industry and government also can impede efforts to maximize the usefulness of the results of taxpayer-funded research, it does not follow that interference by industry and government neutralizes criticisms of university efforts. Similarly, certain critiques of university policies, practices, and behaviors as reflections of approaches to federal policy do not suffer because of a lack of data against which to compare for optimal implementation.

\section{University practices and behaviors evidence a general disconnect with US federal policy that encourages commercializing and using results of taxpayer-funded research}

Through the Bayh-Dole Act, the United States Congress unified under one policy the disjointed and sometimes contradictory approaches deployed by twenty-six federal agencies (Schacht 2010a; Boettinger and Bennett 2006; de Larena, 2007). The essence of the Act is that universities, as against federal agencies, are presumed to have the ability to acquire the right to own and control results of taxpayer-funded research, and once such rights are ensured, universities then have the corresponding ability to prosecute patents and grant exclusive (or non-exclusive) licenses as they deem best for their specific circumstances. In addition, the Act allows researchers to participate in the revenue stream (35 U.S.C. $§ 200$, et seq.). As the Act's purposes make clear, however, Congress intended that this opportunity be accompanied by responsibilities, and Congress emphasized this point as a matter of policy by reserving use and march in rights to the federal government (id.), even though such rights are rarely if ever exercised (Clements 2009).

University leaders, therefore, are charged with designing and implementing policies, procedures, and structures as applicable for their institution to fulfill their responsibilities under the Act and as recipients of federal government research dollars. They are charged with building and pursuing a culture that encourages disclosure of innovations and cooperation with efforts to advance those innovations. Some leaders, such as Michael Crow at 
Arizona State University, have embraced this opportunity at both mission and practical levels. Some leaders speak glowingly in terms of theoretical buy in but, for any number of reasons both within and outside of their control, practical implementation suffers. Other leaders have merely opened technology transfer offices with little or no thought about how the office fits with the university's specific mission, characteristics, or strengths. (See President's Council of Advisors 2008; Lambert and Butler 2006; Nilsson 2006; Schramm 2006; Nelson and Byers 2005; Palmintera 2005; Gordon 2004; Tornatzky 2002).

There are certain practices and behaviors that can reflect leadership's views of advancing innovation and whether or not maximizing research potential is important. Among these are the standards used to measure performance, the nature of resources dedicated to advancing innovation functions, and approaches to certain contracting issues such as decision making, intellectual property, and risk allocation. These are discussed below.

\subsection{University leadership: measurements reflect expectations}

Standards against which performance is measured and rewarded reflect the expectations of those who are assessing performance and what is important to them. As a result, people tend to undertake to satisfy those standards because they are more likely to be assessed and rewarded better. This reality generally supersedes theoretical or policy declarations that might be inconsistent with the measures being taken, which can divert resources and attention from the professed mission and afford disproportionate focus on less than optimal results, incentives, and strategies (NRC 2011). Therefore, analyzing what it is that universities measure regarding efforts to advance innovation will likely reflect the expectations and priorities of leadership and can be a reliable predictor of the behavior that university personnel will pursue, including researchers and those in technology transfer. Standards of measure that promote tactical implementation of Bayh-Dole probably expose a limited, tactical view of the Act; whereas, measures that reach beyond the Act's tactics more likely reflect a broader appreciation of the Act's policy purposes and are more likely to result in behaviors consistent with that end-commercialization, utilization, and public availability.

Universities typically measure such things as the following:

- revenue generated from fees, royalties, options, and cashed in equity;

- the number of disclosures;

- the number of patent applications, patents and licenses or assignments; and

- the number of business start ups begun and ongoing.

(AUTM 2005, 2007a, b, 2008). These data categories are important for understanding aspects of university technology transfer, and its collection, availability, and analysis should continue. However, it is not clear that these measures most fully evidence pursuit of Bayh-Dole's broad purposes (NRC 2011; Tyler 2009).

For instance, many university leaders view revenue as the most important of the measurements. Unfortunately, too many university leaders expect financial "home runs" or blockbusters from their technology transfer (Boettinger and Bennett 2006; Schramm 2006; Libecap 2005; Markman et al. 2005; Bok, 2004b; Mowery et al. 2004; Good 2004), and sometimes those events do occur (Clements 2009). In reality, high dollar producing transactions are very rare and even the amount of revenue generated from all transactions is generally not significant relative to university budgets or even the expense involved with operating a technology transfer office (de Larena 2007; Pizzo 2007; Nilsson 2006; Lambert and Butler 2006; Bok 2004b; Good 2004; Mowery et al. 2004; Seipman 2004; Stein 2004). The general return on investment relative to research dollars expended and technology 
transfer costs incurred does not yet support profitability as a viable business model for technology transfer (Tyler 2009; Clements 2009), particularly when fewer than half of university technology transfer offices have revenue that exceeds their expenses (Clements 2009; Bok 2004a). Despite the realities, expectations held by university leaders too often emphasize revenue as the primary or even exclusive objective (Boettinger and Bennett 2006; Washburn 2005; Markman et al. 2005; Rai and Eisenberg, 2003). This expectation reflects a narrow, tactical view of Bayh-Dole rather than one that seeks to maximize commercial and usefulness potential.

In that environment, those involved can lose sight of solid financial "base hits" that in the aggregate might even produce substantial revenue. They also can neglect innovations that advance human welfare in large or small ways but lack an immediate, vibrant commercial market. While it is easy to blame lack of attention to such non-commercially viable innovations on the lack of a financial return, federal policy espouses dual objectives: commercialization (which may be financial) and utilization (which probably is not). Moreover, nonprofit organizations, private foundations, and government are increasingly prepared to invest significant amounts to bring about cures, treatments, preventatives, and technologies that advance human welfare in meaningful ways that may not support desired market-rate returns.

In short, monetary tunnel vision can result in too many taxpayer-funded research outcomes not being commercialized or used, much less maximized, in which case there is a disconnect between federal policy and university practices.

The other measures identified above are less of a factor as far as potential for distracting those involved from pursuing the Act's purposes. However, these measures reflect a linear view of university innovation derived from a manufacturing or industrial economy that is not consistent with the non-linear or less linear, iterative ecosystem that characterizes our current and future economy and uses for university innovations (Schacht 2010c; Tyler 2009; President's Council of Advisors 2008; Duderstadt 2004).

Moreover, these measures reflect a particular grounding in a patent licensing model for advancing university innovation, one of many different approaches (NIH 1999). As is discussed more below, being grounded in that model neglects the potential that other models present to more fully commercialize and use the results of taxpayer-funded research. Consequently, while numbers of disclosures and transactions are relevant, they are limited in what they convey and over-reliance on them as standards of measure and performance can unnecessarily limit the strategies and models a university uses to advance its innovations.

Additional measures might be more conducive to pursuing federal policy objectives and better reflect a commitment to advancing innovation in furtherance of economic growth and human welfare, which are not mutually exclusive from revenue. Among these might be the following:

a. number of people who use or benefit from the innovation;

b. number of times an innovation is used in total;

c. number of products to which the innovation is deployed;

d. number of licensees and sub-licensees;

e. number of medical treatments administered;

f. number of diseases or health effects treated or prevented;

g. number of lives saved or improved;

h. number of jobs created or retained;

i. total economic impact, including sales volume, revenue, and income and other taxes generated (and exempted because of tax status); 
j. number of new businesses that emerge (e.g., ebay businesses, iphone application businesses, etc.);

k. regional economic development effects;

1. number of social networks created, enhanced, and expanded; and

m. number of new collaborations.

(Tyler 2009; see also Litan and Cook-Deegan 2011). Not all of these will apply for every innovation or even most of them, and several of them will be very difficult to calculate and could impose burdens on licensees that should be evaluated. But these types of measures reflect a very different approach to and expectations of university innovation than the financial and linear measures that currently predominate (President's Council of Advisors 2008). These types of measures also could attract different sources of funding for research and to support commercialization and utilization efforts. These measures also could motivate more disclosures and greater cooperation from altruistic researchers (Nilsson 2006).

What universities most commonly measure and emphasize regarding advancing innovation reflect the expectations of university leadership. When those measures are financial and linear, people are more likely to respond with behavior that favors those measures, which do not necessarily best encourage maximizing the usefulness of the results of taxpayer-funded research and can interfere with efforts toward that end. Other measures can better reflect expectations more consistent with federal policy objectives and better motivate behavior toward that end.

\subsection{University leadership: resources reflect priority}

University technology transfer offices are notoriously under-resourced financially and with personnel, in terms of both headcount and expertise. Of course, the same can probably be said about many if not all administrative offices at universities. Consequently and contrary to what the title to this section might suggest, considering only financial resources and headcount dedicated to efforts to advance university innovation may not accurately reflect the priority that university leaders assign to those efforts. After all, there are many worthy, competing opportunities within a university that will not be fully funded. However, within advancing innovation, there are other ways in which resources can reflect the priority of that function for the institution and its leadership and the priority of purposes within that function, whether revenue, licenses or patents, commercialization, utilization, and/or knowledge dissemination.

For instance, the skill sets of the people who advance university innovations can make a critical difference to the success of those efforts. While content expertise can be beneficial, several studies have identified "bridge building," networking, "boundary spanning," and similar qualities as of primary importance for the people who advance university innovations (CREST 2006; Siegel et al. 2003a; Siegel 2004; Siegel and Phan 2005). These people must earn and nurture the trust of academic researchers and people from industry, either of whom could have conflicting or even mutually exclusive perspectives regarding the other. Consequently, the resources that university leaders dedicate to the strategies they use to define advancing innovation jobs-including TTO personnel and researchers-and otherwise informing decisions about hiring people to these functions can reflect the leaders' views on technology transfer as tactic or policy.

Another way in which advancing innovation resources reflect the priorities of university leaders is the extent to which leaders encourage and actively facilitate interaction among TTO personnel and other internal and external networks that might be useful. Leadership can support advocacy and systems to measure and reward interdisciplinary interaction among 
researchers and with TTO personnel. Leaders can access alumni and university benefactors to provide strategic counsel, distribution opportunities, and substance expertise, including possibly for engaging advisory or decision-making bodies to vet disclosures to the TTO (Litan and Cook-Deegan 2011; NRC 2011). Leaders who deploy their time, networks, and expertise to support and encourage these types of relationships and activities and actually make relevant connections demonstrate that advancing innovation is a priority for them.

Among other resources available to university leaders are the university's incentive and reward systems (Clements 2009). For instance, leaders should understand how to use these systems to encourage researchers to disclose their results and cooperate in efforts to advance those results. They should appreciate that researchers often are motivated most by professional prestige and recognition (Siegel et al. 2003b; Tornatzky 2002), improvements to their research environment and equipment (Nilsson 2006; Strandburg 2005; Siegel et al. 2003a; b), the exchange and testing of ideas (Nilsson 2006; Siegel and Phan 2005; Siegel et al. 2003a), and improved job possibilities for their students (Nilsson 2006). Of course, financial rewards can also be meaningful (Nilsson 2006; Siegel et al. 2003b) and may in some cases be determinative (see Audretsch and Aldridge 2010). University leaders for whom advancing innovation is a priority will find and encourage processes and systems that use these motives effectively, and if existing processes and systems are counterproductive or inadequate, they will find creative ways to modify them and/or develop new approaches. Similarly, these same university leaders will find ways to show that they understand what motivates desired behavior from the others involved in the advancing innovation chain, such as TTO managers and employees.

Another resource that university leaders may deploy is the institution's decision making processes, which can facilitate or hinder efforts to advance innovation. These processes can be a source of unhelpful anxiety and stress for those engaged in it. They can also increase the time it takes to consummate a transaction and the costs associated with doing so, both for the university and other contracting parties. University leaders who undertake and support efforts to make these processes more efficient and less bureaucratic demonstrate that advancing innovation is a priority for them and the university.

Consequently, university leaders have many non-financial resources at their disposal to evidence the degree to which advancing their university innovations is important to them and consistent with pursuing Bayh-Dole's tactics or policies.

\subsection{University leadership: contracting philosophies reflect value}

There are at least three specific aspects of contracting that can reflect the views of university leaders on the value of advancing innovation and have the effect of either facilitating or interfering with that process. These include whether the overall contracting philosophy is reasonably customized or suggests a "one size fits all" approach, whether a variety of strategies for managing the intellectual property are deployed as appropriate to the circumstances or if a particular strategy predominates regardless of circumstances, and whether there is an appropriate and realistic recognition of risk and its allocation. Certain approaches are more likely to facilitate maximizing the usefulness of research results while others are not.

\subsubsection{Approaches to advancing innovation: one size does not fit all}

There are a multitude of approaches to advancing innovation, and it is unlikely that replicating any institution's approach will succeed, regardless of how admired or successful the copied program is. This is not to suggest that every program must be created 
from scratch or that there is nothing to be learned from the successes, frustrations, and experiences of other institutions. However, every university's ecosystem for advancing their innovations is unique, which requires more strategic thought than merely identifying Stanford, MIT, North Carolina, or WARF as the model to be adopted because their model works for them within their ecosystem (Tyler 2009). The best evidence for this point is that Stanford, MIT, North Carolina, and WARF have distinct models; they do not replicate each other! There is no one, single, universal approach to pursuing the mandates of Bayh-Dole (President's Council of Advisors 2008; Lambert and Butler 2006; Nilsson 2006; Palmintera 2005; Gordon 2004; Tornatzky 2002). Unfortunately, there has too often been a potentially damaging pattern of ill-conceived imitation (NRC 2011).

Reflexive replication-that is replicating systems without due consideration to the propriety and appropriateness of those systems for the imitating institution-can result in adoption of protocols without understanding their origination, application, or nuances. Such a strategy allows an institution to say it has a technology transfer office and maybe even to declare that it has patents, licenses, and revenue, but reflexive replication is not likely to achieve Bayh-Dole's purposes, satisfy federal policy objectives, or optimize the potential usefulness of research results. Such strategies can lead to blanket rules and bureaucracy that inhibit advancement rather than facilitate it, despite the best of intentions (Tyler 2009).

Instead, university leaders pursuing the Act's policy objectives will develop and promote advancing innovation systems, including strategic adaptations from among strong programs, based on their knowledge of the university and its mission, the strength of its research personnel and other assets, a vision for success, and understanding of the broad characteristics of the university's ecosystem-all of which will inform practices and behavior more likely to enhance commercialization, utilization, and public availability of the university's innovations (Tyler 2009; see also NRC, 2011).

These universities also might have templates or standard agreements available as a possible starting point for expediting negotiations as distinguished from using such documents as the presumed last best offer. There often are terms that experienced personnel know to expect relative to a given innovation; likewise, there may be generally acceptable ranges of options that repeatedly appear in conjunction with certain types of innovations. In these circumstances, well developed, reasonably vetted, and fundamentally fair templates and standard licensing agreements can shorten the cycle time for moving innovations from lab to market (Crow 2008). Arizona State uses template licensing and master sponsored research agreements (Crow 2008). The University of North Carolina at Chapel Hill uses its "Carolina Express" standard licensing agreement as one approach for licensing to start up companies with faculty or student owners (Litan and Cook-Deegan 2011). Georgia Tech negotiates master agreements that contain the basic terms of relationships with more specific engagements implemented using task orders governed by the master agreement (Bohlander 2004). Such efforts to streamline these processes can be particularly useful and relevant with research tools (NIH 1999) and when licensing to startups, especially those with faculty and student involvement (NRC 2011).

The key is to devote the time and energy necessary to develop a system and approaches that best fit the university's assets and vision for advancing its innovations, including ongoing evolution of the system and approaches (Tyler 2009; NRC 2011).

\subsubsection{Perspectives on intellectual property}

Bayh-Dole does not require that universities patent the results of their research or even that they retain ownership. The Act provides certain presumptions so that universities could 
have the freedom and flexibility to assess multiple courses of action and to exercise its judgment about the best path under the circumstances, whether licensing, selling, commercializing itself through spin out companies, or simply making available for general use. The patent-licensing model that the Act seems to encourage as a tactic is only one of several approaches to maximizing the usefulness of the results of taxpayer-funded research, but many technology transfer offices seem to over-rely on this model, sometimes regardless of the circumstances (NRC 2011; Boettinger and Bennett 2006; President's Council of Advisors 2008).

Patenting is not right for every innovation. For instance, patent protections may be essential for biomedical or pharmaceutical innovations, but speed to market may be more important in communication and information technology fields (Schacht 2010a; Mowery et al. 2004; President's Council of Advisors 2003; Rai and Eisenberg 2003). Pursuing patent strategies in the latter areas could result in the innovation being obsolete with corresponding lost opportunities, wasted time and money, and ultimately non-use. Patenting is also less relevant where duplication is expensive, complicated, and time consuming or if the patent can be evaded because of the ease of inventing around it (Schacht 2010a).

Universities that seek to maximize potential usefulness recognize that any number of factors can influence the IP strategy, including the nature of the innovation, the stage of development, market potential, and competition (Mowery et al. 2004; Rai and Eisenberg 2007; Siegel and Phan 2005; Markman et al. 2005). They also recognize and use a variety of IP strategies appropriate to the circumstances and ultimate objectives, including patenting or not, exclusivity or not, Science Commons or not, and whether to limit the field of use, reserve rights for non-commercial research, prefer a university spin out, or any number of other matters, including public domain. They also understand that various strategies may inter-relate such that asserting or reserving rights or expectations in one term or condition may be offset in others.

There are degrees to which the so-called "Nine Points" are helpful in encouraging universities to at least be aware of these and other relevant issues (Stanford University et al. 2007). ${ }^{1}$ Elements of certain of the recommendations appropriately seek to further aspects of university missions that deal with education, research, and benefits to society. Among these are those that deal with reserving certain research rights (1), ensuring broad access to research tools (5), and considering ways to serve neglected populations and areas (9). The presumptive desire to see exclusively licensed inventions developed and used (2)

\footnotetext{
1 In 2007, twelve institutions with active technology transfer practices adopted and disseminated a group of nine recommendations that the participants found they had in common. The Nine Points are as follows:

1. Universities should reserve the right to practice licensed inventions and to allow other non-profit and governmental organizations to do so.

2. Exclusive licenses should be structured in a manner that encourages technology development and use.

3. Strive to minimize the licensing of "future improvements."

4. Universities should anticipate and help to manage technology transfer related conflicts of interest.

5. Ensure broad access to research tools.

6. Enforcement action should be carefully considered.

7. Be mindful of export regulations.

8. Be mindful of the implications of working with patent aggregators.

9. Consider including provisions that address unmet needs, such as those of neglected patient populations or geographic areas, giving particular attention to improved therapeutics, diagnostics and agricultural technologies for the developing world.
} 
instead of simply shelved is valuable as long as there is flexibility in the standards against which progress is assessed that contemplates the early stage of much university research and that applications may not be apparent (Schacht 2010a; NIH 1999, 2005). In addition, the recommendation that universities identify and manage conflicts of interest (4) rather than quixotically seek to eliminate them ultimately helps protect the university, the researcher, and even the licensee (Tyler 2009). Unfortunately, however, aspects of the Nine Points are problematic.

For instance, point 1 encourages a reservation of rights to "practice" the licensed invention and permit other non-profits and government entities to do likewise. While arguably reasonable to reserve rights narrowly tailored to permit ongoing academic research (NIH 2005), the recommendation is broader than that. Although there is useful language in the appendix that restricts such practice to "non-commercial, research purposes," the recommendation as written neither states nor implies such an application and not all of the examples in the appendix reflect such a limitation. The ability to broadly "practice" the invention and permit non-profit and governmental entities to do the same could effectively undermine or materially diminish the licensee's market potential. At worst, adopting this recommendation broadly as written invites-maybe even requiresexpenditure of time and expense by the university and licensee to negotiate a more reasonable, narrower application.

A further problem arises when broad rights to practice the invention are combined with expectations that universities "minimize the licensing of "future improvements" (3). Although universities might generally refrain from licensing that which does not yet exist, as distinguished from granting first rights to negotiate, reserving rights to improvements to an already licensed invention could allow the university to license improvements to a different maybe competing licensee, which could undermine benefits to the initial license. Such an arrangement could materially reduce the original licensee's incentives to invest the substantial amounts normally required to transform research results into useful products.

In addition, as written, this point three suggests that universities deny licensees rights to improvements made by the licensee even though, given the basic nature of much university research, it is precisely these improvements that may be most useful to the licensee. Fortunately, the accompanying explanation of the point implies that it is intended to minimize licenses to improvements derived from the university's ongoing research, and the proposed language in several (but not all) of the examples in the appendix usefully demonstrates this application. But the express language of the recommendation, which might have been qualified by the addition of a few words, would deprive the licensee of all rights to improvements, even those that the licensee's research might reveal.

Without some limits on the university's ability to license its improvements to others and without some access to future improvements (at least those generated by the licensee), a commercial licensee could find that it has invested heavily to prove a concept or develop a market that its competitors can then prematurely exploit to the licensee's detriment.

Other concerns about the Nine Points are more general and are informed in part by four broad observations. First, there is an unfortunate pattern of non-strategic imitation among universities regarding technology transfer that the National Academies' National Research Council and others have identified and discouraged. Second, the Nine Points are highly nuanced and subject to subtle qualifications that many university leaders or others may not have time to understand. Third, the presented concerns may not be as relevant for the more sophisticated and advanced universities, but the Nine Points are not likely targeted to them in any event. Ultimately, these concerns culminate in a fear that, instead of facilitating more frequent and efficient transfer efforts, certain of the recommendations might be 
implemented badly and result in either not changing the status quo or that the changes are to the detriment of speed, savings, and energy.

Among the general concerns is the fact that, even though the drafters acknowledge the complexity of licensing and multiplicity of factors, it may be too easy to apply the points in isolation. Such an approach would reduce that which the licensee receives or impose demands on the licensee without corresponding reductions in what the university receives (e.g., royalty rates, equity, license fees, reversion rights, etc.) or increases in other benefits to the licensee (e.g., time, scope, area, field, etc.). A point 10 that acknowledged the interrelatedness of terms and recognized the appropriateness of using other provisions to offset the demands of the Nine Points might have been productive.

Another concern is that the Nine Points could be construed as suggesting that shelving an invention may be a better alternative than conceding on applicable points even if conceding could yield public, social, or other benefits of greater proportion or significance than the decreased benefits to the university by making the relevant concession. This concern could become particularly problematic if universities incorporate certain of the Nine Points into tools for measuring performance or effectiveness or if they are elevated from tactical considerations to strategic or even mission level mandates.

Finally, the Nine Points inherently emphasize a model for transferring technology based on university control and licensing. As such, implicit in prestigious and respected institutions meeting and producing this document is the possible message that university leaders and others should prioritize this approach to the detriment of other potentially useful approaches. It also could be inferred that inventions not ready for licensing are not (or should not be) ready for substantive attention despite the alternatives for both strategies and attention.

Thus, if implemented without qualification, these suggestions might actually impede transfer or advancement instead of facilitating it. In light of having been available for several years and endorsed by 89 entities as of August 2011, perhaps an in-depth, objective assessment of their effect on and implementation by endorsers, non-endorsers, and licensees might assuage the concerns presented here.

Among the alternative strategic options available to universities is relinquishing control rights, frequently while retaining some financial interest, to the researcher for him or her to pursue or allow others to pursue strategies for commercialization and/or utilization. In light of Bayh-Dole's policy objectives, relinquishing rights better positions innovations for usefulness than does failing to make any choice and letting discoveries languish.

A variation of this approach could be for universities to retain financial interests but otherwise presumptively permit its researchers to control the destiny to commercialization or utilization by choosing to engage the university's TTO, another university's TTO that specializes in the relevant innovation, or even a private third party to manage the transfer activities (Litan and Cook-Deegan 2011; Mitchell and Litan 2010). This might lead to development of consortia among universities within geographic areas or with expertise in a particular substantive vertical (Litan and Cook-Deegan 2011). A further market could develop for others to recognize and pursue opportunities to fill such a nice (id.).

A third, related option might be to allow the university a certain time within which they must exercise control and then pursue commercialization and/or utilization against certain milestones after which control automatically reverts to the researcher.

These approaches are not right for every type of innovation, but there are applications for certain types that are worth exploring.

University leaders who value the broad policy objectives of Bayh-Dole appreciate the need for multiple pathways to achieve those objectives. They empower their researchers 
and technology transfer personnel with appropriate authority to pursue the best transaction that furthers these purposes, which may or may not be measured in dollars, and that reasonably protects and rewards the university and researcher.

\subsubsection{Strategies for realistically and appropriately allocating risk}

The nature of university research is such that its results frequently are at early or prototype stages of development when technical and market applications and potential are often uncertain (NRC 2011; Schacht 2010a; Nilsson 2006; NIH 2005; Markman et al. 2005; Mowery et al. 2004). In any case, commercialization and utilization are not likely to occur without spending more time and money and devoting more expertise to testing, market analysis, and modifications (Mowery et al. 2004; Siegel et al. 2003a; Pulsinelli 2006) —all subject to the vagaries of market timing and demand. When developing policies and philosophies for advancing their university's innovations, university leaders should understand these realities and encourage standards of measure and negotiating positions that reflect them.

These leaders also should appreciate other risks that are allocated in a transaction, including risks that the researcher's innovation infringes someone else's rights or is not accurate. Anyone who commercializes or utilizes the results of that research risks exposure to liability, or at least costs of defense, based on those infringements or inaccuracies. These risks as they relate to the research results are often allocated based on the presence and quality of the university's (and researcher's) representations, warranties, or covenants, the presence of an indemnification obligation or hold harmless language, and the university's ability or responsibility to rely on sovereign immunity. How a university approaches these issues can reflect the philosophy it and its leaders have toward advancing innovations and Bayh-Dole (Tyler 2009).

For instance, the university is in a much better position than industry to supervise researchers and hold them accountable for the integrity of their research and its results, even with academic freedom and other circumstances of academia (de Larena 2007). It does not seem unreasonable for university leaders to expect deans, department chairs, fellow researchers, and technology transfer personnel to protect the university's interest in credible research (de Larena 2007; CREST 2006), which transcend technology transfer in any event to reflect the university's overall academic and research reputation (CREST 2006). Not only that, but universities often demand and receive amounts in grants dedicated to administrative costs, some of which can be used for monitoring (de Larena, 2007). Because these interests are aligned, it can be disingenuous for universities to take the position in transfer negotiations that they cannot provide representations or indemnification. Universities sometimes automatically take this paradoxical position as a matter of policy or practice without necessarily considering whether the university has protected itself vis a vis the researcher or whether to compromise other positions (e.g., royalty rates, field of use, etc.) in recognizing that it is shifting these risks to the other party (Tyler 2009).

An extreme, but not unheard of, version of this behavior is for a university to demand that its licensee indemnify the university if the research results it is licensing infringe or if the university actually lacks the right to license it. This practice inhibits commercialization and utilization and undermines the Act's purposes. It also reflects a deep misunderstanding of advancing innovation. This inherently obstructionist practice should be distinguished from legitimate expectations that the licensee indemnify the university for the licensee's actions and behavior regarding the licensed innovation. 
Allocating risk for liability arises in unique ways for those who transact with public universities who, as arms of government, may claim the protections of sovereign immunity. This doctrine may relieve or limit liability of governmental bodies for infringing behavior or even breaching contracts, except to the extent government has agreed to accept such liability. Consequently, sovereign immunity could force a victim of university infringement to pursue the best available alternative - the party to whom the university licensed its innovation. In that case, the licensing party is accepting greater risk and the university should be aware of that re-allocated risk as part of the deal being struck.

Another way in which these issues reflect leadership's views on advancing university innovations is the clarity with which university personnel are authorized to make decisions on these types of matters. This can be a particularly troublesome issue if the university has involved the TTO, legal counsel, risk management, and possibly an administrator or others in the negotiations. With so many interests being represented, a lack of clarity about what responsibility and authority each has for making decisions can lead to unnecessarily protracted and more expensive negotiations, confusion within the university and for the other party, and frustration for all involved (Tyler 2009).

This section should not be read to suggest that universities should be reckless in retaining risk and accompanying liability. The purpose of this section is to encourage university leaders to understand that risk is allocated when innovations are advanced, that the university can take reasonably informed positions when allocating that risk, that it should avoid unreasonable and uninformed positions, and that the overall terms of the transaction should compensate for the risk as actually allocated. This approach is more consistent with ensuring that university innovations are commercialized, utilized, publicly available, and otherwise advanced.

\section{Conclusion}

The Bayh-Dole Act has made a positive difference in how US universities advance their innovations and the pace at which they do so. As a result, society has benefited because of contributions to economic growth through new jobs, companies, and even whole industries. In addition, university innovations have contributed to advances in human welfare more generally. The United States Congress recognized the potential for these outcomes when it enacted Bayh-Dole in 1980 and the federal government continues to believe in this potential as evidenced by the tens of billions of dollars it directs each year to support university research efforts.

Unfortunately, too often universities and their leaders focus on the tactics provided for in the Act and lose sight of the Act's broader purposes of preventing non-use of research results funded with government dollars and encouraging commercialization, utilization, and public availability of those results. Too many consider the tactics as ends in themselves rather than tools to be used to further larger purposes. They too frequently deploy standards for measuring performance that reflect this narrow, linear focus and in the process neglect broader, iterative opportunities. They may not do enough to dedicate resources to advance the university's innovations, including committing time and expertise to ensuring appropriate skill sets for advancing innovation on staff and as advisors, promoting inter-disciplinary interactions for the benefit of researchers and advancing innovation personnel, creatively using and targeting incentive and reward systems to encourage engagement and pursuit of the Act's purposes, and ensuring a contracting system that most clearly delineates responsibility and authority. They may not give their advancing innovation functions 
enough strategic thought but instead pursue wholesale adoption of another university's successful model as a "one size fits all" approach to serve their needs. They may overly rely on one or a few transfer strategies without regard to the nature of the underlying intellectual property, licensee, or opportunity. Finally, they too often have unrealistic views of risk with the consequence that their approaches to contracting attempt to misallocate risk, liability, and reward.

Each of these considerations can interfere with commercializing or utilizing university discoveries or their publicly availability.

The suggestion that US universities do more to pursue and optimize the potential usefulness of the results of taxpayer-funded research is not an acclamation that US universities have failed. Instead, it is a suggestion that they can improve and, in doing so, better advance economic growth and human welfare. Paraphrasing from elsewhere in this article, better than it was is no excuse for failing to pursue or even achieve as good as it could be.

Open Access This article is distributed under the terms of the Creative Commons Attribution Noncommercial License which permits any noncommercial use, distribution, and reproduction in any medium, provided the original author(s) and source are credited.

\section{References}

Association of University Technology Managers. (2005). AUTM US Licensing Survey Summary: FY 2004. Association of University Technology Managers. (2007a). AUTM US Licensing Survey Summary: FY 2005. Association of University Technology Managers. (2007b). AUTM US Licensing Survey Summary: FY 2006. Association of University Technology Managers. (2008). AUTM US Licensing Survey Summary: FY 2007. Audretsch, D., \& Aldridge, T. (2010). Does policy influence the commercialization route? Evidence from National Institutes of Health Funded Scientists. Research Policy, 39(5), 583-588.

Boettinger, S., \& Bennett, A. (2006). The Bayh-Dole Act: Implications for developing countries. IDEA: The Intellectual Property Law Review, 46, 261-281.

Bohlander, R. A. (2004). Pushing the envelope in university involvement with commercialization. In D. Stein (Ed.), Buying in or selling out: The commercialization of the American Research University. New Brunswick: Rutgers University Press.

Bok, D. (2004a). The benefits and costs of commercialization of the academy. In D. Stein (Ed.), Buying in or selling out: The commercialization of the American Research University. New Brunswick: Rutgers University Press.

Bok, D. (2004b). Universities in the marketplace: The commercialization of higher education. Princeton and Oxford: Princeton University Press.

Clements, J. D. (2009). Improving Bayh-Dole: A case for inventor ownership of federally sponsored research patents. IDEA: The Intellectual Property Law Review, 49, 469-515.

Coffman, W. R., et al. (2003). Executive summary and recommendations, IP Strategy Today (pp. 3-7). Ithaca, New York: Cornell University.

CREST OMC Expert Group on Intellectual Property. (2006). Intellectual property: Collaboration between publicly funded research organisations and industry and technology transfer training. CREST OMC. http://ec.europa.eu/invest-in-research/pdf/download_en/crestreport.pdf.

Crow, M. M. (2008). Building an Entrepreneurial University. In The future of the Research University: Meeting the global challenges of the 21st century. Germany and Kansas City, Missouri: Max Planck Institute and Ewing Marion Kauffman Foundation.

de Larena, L. R. (2007). The price of progress: Are universities adding to the cost? Houston Law Review, 43, $1373-1444$.

Duderstadt, J. J. (2004). Delicate balance: Market forces versus the public interest. In D. Stein (Ed.), Buying in or selling out: The commercialization of the American Research University. New Brunswick: Rutgers University Press.

Good, M. (2004). Increased commercialization of the academy following the Bayh-Dole Act of 1980. In D. Stein (Ed.), Buying in or selling out: The commercialization of the American Research University. New Brunswick: Rutgers University Press. 
Gordon, M. (2004). University controlled or owned technology: The state of commercialization and recommendations. Journal of College and University Law, 30(3), 641-672.

Lambert, R., \& Butler, N. (2006). The future of European universities: Renaissance or decay? London: Center for European Reform.

Libecap, G. (2005). Introduction. In G. Libecap (Ed.), University entrepreneurship and technology transfer: Process, design, and intellectual property. Oxford: Springer.

Litan, R. E., \& Cook-Deegan, R. (2011). Universities and economic growth: The importance of academic entrepreneurship. In rules for growth: Promoting innovation and growth through legal reform (pp. 55-82). Kansas City: Ewing Marion Kauffman Foundation.

Markman, G. D., et al. (2005). Entrepreneurship and university-based technology transfer. Journal of Business Venturing, 20(2), 241-263.

Merrill, S. A., \& Mazza, A.-M. (Eds.). (2011). For the National Research Council of the National Academies, Managing University Intellectual Property in the Public Interest, The National Academy Press, Washington, DC (NRC 2011).

Mitchell, L., \& Litan, R. E. (2010). The HBR list: Breakthrough ideas for 2010. Harvard Business Review, Jan 12010.

Moore, C. G. (2006). Killing the Bayh-Dole Act's Golden Goose. Tulane Journal of Technology and Intellectual Property, 8, 151-172.

Mowery, D. C. (2005). The Bayh-Dole Act and high technology entrepreneurship in US universities: Chicken, egg, or something else? In G. Libecap (Ed.), University entrepreneurship and technology transfer: Process, design, and intellectual property (pp. 39-68). Oxford: Elsevier.

Mowery, D. C., Nelson, R. R., Sampat, B. N., \& Ziedonis, A. A. (2004). Ivory tower and industrial innovation. Palo Alto: Stanford Business Books.

Nelson, A., \& Byers, T. (2005). Organizational modularity and intra-university relationships between entrepreneurship education and technology transfer. In G. Libecap (Ed.), University entrepreneurship and technology transfer: Process, design, and intellectual property (pp. 39-68). Oxford: Elsevier.

Nilsson, A. S., et al. (2006). Commercialization of life-science research at universities in the United States, Japan and China. Swedish Institute for Growth Policy Studies: ITPS.

Palmintera, D., et al. (2005). Accelerating economic development through university technology transfer. Reston, VA: Innovation Associates, Inc.

Paytas, J., et al. (2004). Universities and the development of industry clusters. Report prepared by the Carnegie Mellon University, Center for Economic Development, for Economic Development Administration, US Department of Commerce, Pittsburgh, PA.

Pizzo, P. A. (2007). Fostering innovation without compromising integrity. Cleveland Clinic Journal of Medicine (Supplement), 74, S10. Cleveland: Cleveland Clinic.

President's Council of Advisors on Science and Technology. (2003). Report on technology transfer of federally funded R\&D: Findings and proposed actions.

President's Council of Advisors on Science and Technology. (2008). University-private sector research partnerships in the innovation economy.

Pulsinelli, G. (2006). Share and share alike: Increasing access to government-funded inventions under the Bayh-Dole Act. Minnesota Journal of Law, Science and Technology, 7, 393-482.

Rai, A. K., \& Eisenberg, R. S. (2003). Bayh-Dole reform and the progress of biomedicine. Law and Contemporary Problems, 66, 289-314.

Rai, A. K., \& Eisenberg, R. S. (2007). University software ownership: Technology Transfer or business as usual? 28 duke law school science, technology and innovation research paper series, Research Paper No. 20, 2007. http://papers.ssrn.com/sol3/papers.cfm?abstract_id=996456.

Schacht, W. H. (2010a). The Bayh-Dole Act: Selected issues in patent policy and the commercialization of technology, CRS Report for Congress, Order Code RL32076.

Schacht, W. H., (2010b). Technology transfer: Use of federally funded research and development, CRS Report for Congress, Order Code RL33527.

Schacht, W.H., (2010c). Industrial competitiveness and technological advancement: Debate over government policy, Order Code RL33528.

Schramm, C. J. (2006). The entrepreneurial imperative. New York: HarperCollins.

Seipman, T. J. (2004). Global exportation of the US Bayh-Dole Act. University of Dayton Law Review, 30, 209-243.

Siegel, D. S., \& Phan, P. H. (2005). Analyzing the effectiveness of university technology transfer: Implications for entrepreneurship education. In G. Libecap (Ed.), University entrepreneurship and technology transfer: Process, design, and intellectual property. Oxford: Elsevier. 
Siegel, D. S., et al. (2003a). Commercial knowledge transfers from universities to firms: Improving the effectiveness of university-industry collaboration. Journal of High Technology Management Resources, 14, 111.

Siegel, D. S., et al. (2003b). Assessing the impact of organizational practices on the productivity of university technology transfer offices: An exploratory study. Research Policy, 32, 27.

Siegel, D. S., et al. (2004). Toward a model of the effective transfer of scientific knowledge from academicians to practitioners: Qualitative evidence from the commercialization of university technologies. Journal of Engineering and Technology Management, 21, 115.

Stanford University, et al. (2007) In the public interest: Nine points to consider in licensing university technology.

Stein, D. G. (2004). A personal perspective on the selling of academia. In D. Stein (Ed.), Buying in or selling out: The commercialization of the American Research University. New Brunswick: Rutgers University Press.

Strandburg, K. J. (2005). Curiosity-driven research and university technology transfer. In G. Libecap (Ed.), University entrepreneurship and technology transfer: Process, design, and intellectual property (pp. 93-123). Oxford: Elsevier.

Thursby, J. G., \& Thursby, M. C. (2004). Buyer and seller views of university-industry licensing. In D. Stein (Ed.), Buying in or selling out: The commercialization of the American Research University. New Brunswick: Rutgers University Press.

Thursby, J., Fuller, A., \& Thursby, M. (2009). US faculty patenting: Inside and outside the university. Research Policy, 38, 14-25.

Tornatzky, L. G., et al. (2002). Innovation U: New university roles in a knowledge economy. Southern Growth Policies Board.

Tyler, J. E. (2009). Advancing university innovation: More must be expected-more must be done. Minnesota Journal of Law Science and Technology, 10(1), 143-212.

Washburn, J. (2005). University Inc.: The corporate corruption of higher education. New York: Perseus Books Group.

15 U.S.C. $\$ 3701$.

15 U.S.C. $\$ 3702$.

15 U.S.C. $§ 3710$.

15 U.S.C. $\$ 271$.

35 U.S.C. $\$ 103$.

35 U.S.C. $\$ 200$, et seq.

S. Rep. No. 96-480, at 1, 3 (1979).

70 Fed. Reg. No. 68, 18413 (April 11, 2005) (“NIH, 2005”).

64 Fed. Reg. No. 246, 72090 (December 23, 1999) (“NIH, 1999”). 